\title{
Quetiapine Abuse in Illicit Drug Users or Sellers: To Screen or Not to Screen?
}

\author{
Uyuşturucu Madde Kullanıcı veya Satıcılarında Ketiapin Kötüye Kullanımı: Taranmalı Mı?
}

\section{(1) İsmail Ethem Gören, PhD. Student, (1) Nebile Dağlıoğlu, Assoc. Prof.}

Çukurova University Faculty of Medicine, Department of Forensic Medicine, Adana, Turkey

\section{ABSTRACT}

Objective: Abuse of psychoactive drugs for therapeutic purposes is becoming more common due to their addiction potential. In many studies, quetiapine has been reported to be abused with illicit drugs. We aimed to point to the abuse and addiction potential of quetiapine by the rates of quetiapine abuse in blood samples of 4,293 cases who came to our Forensic Toxicology Laboratory by using liquid chromatography-tandem mass spectrometry method.

Methods: All cases who were caught by law enforcement officers while using or trading drugs as a requirement of the judicial process initiated were drug users or dealers and then they were brought to our forensic toxicology laboratory to obtain blood and urine samples. Quantification in blood samples was performed in routine laboratory analysis. The cases were asked whether they used any prescription drugs. The therapeutic drug users were excluded in this study.

Results: Quetiapine was positive in 50 of 4,293 cases (1.16\%). 93.8\% $(n=4028)$ of all cases and all of the positive quetiapine were male. While quetiapine was used alone in 11 of 50 cases with quetiapine positivity, quetiapine was used simultaneously with one or more groups of illicit drugs in the remaining 39 cases.

Conclusion: In this study, the most common use of cannabis and quetiapine was determined in cases with drugs of abuse. The monitoring of quetiapine is essential for preventing drug abuse especially in prone population such as illicit drug abusers and addicts. Forensic Toxicology Laboratories play an important role in taking necessary preventions related to drug abuse.

Keywords: Quetiapine, antipsychotics, psychoactive drugs, abuse, toxicology

Address for Correspondence/Yazıșma Adresi: İsmail Ethem Gören PhD. Student, Çukurova University Faculty of Medicine, Department of Forensic Medicine, Adana, Turkey

E-mail: iegoren@cu.edu.tr

ORCID ID: orcid.org/0000-0002-0219-1598
Received/Geliș tarihi: 15.04 .2020 Accepted/Kabul tarihi: 11.09.2020 


\section{ÖZ}

Amaç: Bağımlılık potansiyelleri nedeniyle terapötik amaçlar için kullanılan psikoaktif ilaçların kötüye kullanımı günden güne yaygınlaşmaktadır. Birçok çalışmada, ketiapinin yasadıșı uyuşturucu maddeler ile birlikte suistimal edildiği bildirilmiştir. Bu çalıșmada, Adli Toksikoloji Laboratuvarımıza gelen 4.293 olguda ketiapinin suistimal oranlarının belirlenmesi amaçlanmıştır.

Yöntem: Başlatılan adli tahkikatın gereksinimi olarak uyuşturucu satarken veya kullanırken kolluk kuvvetleri tarafından yakalan tüm olgular, uyuşturucu kullanıcısı veya satıcısıdır ve daha sonra tüm olgular uyuşturucu madde testi için adli toksikoloji laboratuvarımıza getirilmiştir. Olguların kan örneklerinde rutin laboratuvar analizinde kullanılan valide metot kullanılarak kantitatif, idrar örneklerinde kalitatif analiz çalıșılmıştır. Olgulara herhangi bir reçeteli ilaç kullanıp kullanmadıkları sorulmuștur. Terapötik ilaç kullanıcıları çalışmaya dahil edilmemiștir.

Bulgular: Dört bin 293 olgunun 50'sinde $(\% 1,16)$ ketiapin pozitif bulunmuştur. Tüm pozitif olgular erkektir. Ketiapin tek başına 11 olguda tespit edilirken, diğer olgularda bir veya daha fazla yasadıșı ilaçla birlikte ketiapin kullanımı söz konusudur (n=39). Kan örneklerinde ölçülen ketiapin konsantrasyon aralığı 0,46-411 ng/mL (ortalama: 56,4 ng/mL)'dir.

Sonuç: Bu çalışmada, yasadışı ilaç kullanıcıları arasında ketiapin ile birlikte en sık tespit edilen madde kannabis (esrar) olmuştur. Ketiapinin takip edilmesi, özellikle yasadıșı uyușturucu kullanıcıları ve bağımlıları gibi eğilimli popülasyonda uyuşturucu kullanımının önlenmesi için önemlidir. Adli Toksikoloji Laboratuvarları, bu verileri ilgili yasal birimlerle paylașarak uyușturucu bağımlılığı ile ilgili gerekli önlemlerin alınmasında önemli bir rol oynamaktadır.

Anahtar Kelimeler: Ketiapin, antipsikotikler, psikoatif ilaçlar, kötüye kullanım, toksikoloji

\section{INTRODUCTION}

The abuse of psychoactive drugs used for therapeutic purposes is becoming widespread at the present time. The case reports and data of poison centers associated with the potential for abuse or misuse of quetiapine, which is included in secondgeneration antipsychotic drugs, by oral, intranasal, and intravenous administration has indicated that quetiapine abuse is a common phenomenon in the last decade (1-3). The use of the drug in the treatment of psychiatric disorders such as bipolar disorder and schizophrenia is approved by the US Food and Drug Administration (4). It can also be used in the treatment of mood disorders, anxiety and major depression, alcohol and drug addiction in the clinic (5). Quetiapine abuse can result in a variety of undesirable sensory changes, including anxiolysis, hypnosis and euphoria $(3,6)$.

In terms of receptor activity, it has the characteristics of a potent serotonin 5 - $\mathrm{HT} 2 \mathrm{~A}$ receptor antagonist and a moderate dopamine D2-receptor antagonist, partially 5-HT1A agonist, $\mathrm{H}_{1}$ histamine antagonist, $\alpha_{1 / 2}$ adrenoreceptor antagonist and sigma1 receptor agonist. Its half-life is approximately 6 hours. While quetiapine has no significant activity on cholinergic, muscarinic and benzodiazepine receptors, it acts mainly on serotonergic, dopaminergic and adrenergic receptors (7). In particular, drug-induced dopamine release in the limbic system (ventral striatum) is associated with drug dependence and abuse. Considering that animal studies are an indirect tool for the assessment of drug addiction, it is concluded that quetiapine affects the neurological system associated with drug abuse and that the drug has the potential for psychological dependence (8). Although the majority of prescribed quetiapine has been used for clinical purposes, some patients can easily obtain and abuse the drug (9). The fact remains that the drug is not included controlled substances in Turkey and its drug abuse potential is often ignored (10).

In many studies, quetiapine has also been reported to be simultaneously abused with other illegal drugs, including sympathomimetic such as cocaine, and amphetamines $(11,12)$. The frequency of quetiapine usage in these cases has attracted our attention while drug testing was performed in the biological samples of drug of abuse cases due to use of illegal drug. In this cross-sectional study, we evaluated whether quetiapine screening is needed in routine toxicological analysis of all cases by detecting the rates of quetiapine usage and its concentrations in the blood samples of 4,293 patients who came to our Forensic Toxicology Laboratory between 2017 and 2018 years.

\section{MATERIALS and METHODS}

In this study, blood samples of 4,293 patients who were sent to forensic toxicology laboratory on suspicion of illicit substance supply and trade between 2017 and 2018 years were examined. All of the cases are individuals who were caught by law enforcement officers and started the judicial process while using or trading drugs. These cases were brought to our forensic toxicology laboratory in order to obtain blood and urine samples for drug testing as a requirement of the judicial procedure. Urine samples were prepared by liquid-liquid extraction method and analyzed qualitatively.

\section{Chemicals}

All chemicals used in the extraction stage in the analysis of illicit substances and drugs are of the purity of chromatography and Merck brand (Merck, Gibbstown, NJ, USA). All the standard and internal standard (diazepam-d5) Lipomed brand (Lipomed, 
Cambridge, USA) used to plot the calibration curves were used in quantitative analysis.

\section{Analysis of Illicit Substances and Drugs in Blood Samples}

\section{Solid Phase Extraction}

Solid phase extraction (SPE) cartridges (OASIS HLB, 3 cc $60 \mathrm{mg}$ ) (Waters, Milford, MA) used for SPE were conditioned with 2 $\mathrm{mL}$ methanol and $2 \mathrm{~mL}$ ultrapure water. $1 \mathrm{~mL}$ of whole blood and $2.5 \mathrm{~mL}$ of ultra-pure water were centrifuged at 3,500 rpm and supernatants were added to the conditioned cartridges. Cartridges with blood samples were washed with $5 \%$ methanol solution and dried under vacuum for 10 minutes. The eluent was taken up with ethyl acetate/ $\mathrm{NH}_{4} \mathrm{OH}(98: 2)$ solution and then dried under pure nitrogen. It was then dissolved with $1 \mathrm{~mL}$ of methanol and mixed with vortex, then $0.22 \mu \mathrm{m}$ polytetrafluoroethylene syringe tip was filtered through filters and placed into $1.5 \mathrm{~mL}$ amber glass vials. The concentrations of illicit substances and drugs in the extracted blood samples were determined by Liquid chromatography-tandem mass spectrometry (LC-MS/MS).

\section{Analysis of Illegal Substances and Drugs with LC-MS/MS}

Illegal substances and drugs were analysed by Shimadzu CBM-20A ultra-flow LC, Shimadzu SIL-20A/HT automatic sampling system and Shimadzu 8,040 mass spectrometer. The analyte separation was obtained using a mixture of 10 $\mathrm{mM}$ ammonium formate in water as mobile phase $A$ and methanol gradient as mobile phase $B$. The drugs and drugs were separated on a pentafluorophenylpropyl column (Allure 50×2,150 mm, 5 umm, Restek, Bellefonte, PA, USA). The analysis was performed in multiple reactions monitoring (MRM) mode. Positive MRM was used for all items (Table 1). Two MRM transitions were followed for the detection of each substance, the first used for determination and the second used for confirmation. The total working time of the method is 13 minutes. Total flow rate for analysis was $0.4 \mathrm{~mL} / \mathrm{min}$. and the injection volume of the samples is $20 \mu \mathrm{L}$. Quantitative analysis of quetiapine was performed in blood samples and the calibration points were 1, 2.5, 5, 10, 25, 50, 100, 250, 500 $\mathrm{ng} / \mathrm{mL}$.

\section{RESULTS}

The cases of quetiapine positivity were evaluated in cases of illegal substance and drug analysis in cases who came to the Forensic Toxicology Laboratory in Faculty of Medicine at Cukurova University. Accordingly, quetiapine was found to be positive in 50 cases (1.16\%) among 4,293 cases. 93.8\% of all cases were male $(n=4,028)$. All 50 cases were forensic and all cases belonged to male individuals. The mean age of the cases with quetiapine positive was 36.7 years \pm 8.3 standard deviation (SD) (22 to 59 years). The quetiapine concentrations detected in the blood samples of the subjects ranged from
0.46 to $411.0 \mathrm{ng} / \mathrm{mL}$ (median: $8.6 \mathrm{ng} / \mathrm{mL}$, mean: $56.4 \mathrm{ng} / \mathrm{mL}$ \pm 117.7 SD). Blood samples of all the cases in which quetiapine was found positive. Quetiapine was not detected in the urine sample of only 8 cases. In cases where quetiapine was detected, quetiapine alone was abused as well as its multiple use with illegal substances.

Quetiapine alone was detected in 11 of the 50 quetiapine positive cases, while quetiapine was used with one or more drug groups in the remaining 39 cases (Figure 1).

When quetiapine is used with a single substance, it is mostly used in combination with opiate substances (25\%). This is followed by use with cannabis and amphetamine-derived illegal substances, respectively.

In the other cases, the use of quetiapine with more than one illegal substance was determined. The use of quetiapine only with cannabis drugs was found in 8 cases. In the other cases where quetiapine was used together with drugs, it was determined that drugs were used simultaneously in more than one group (Table 2).

\section{DISCUSSION}

The development of drugs designed with clinically effective sedative, analgesic, anxiolytic, anaesthetic and stimulant properties has led to the abuse of these drugs (13). Among the most obviously abused antipsychotic drugs, quetiapine is one of the most remarkable drugs. According to the data of the American Association of Poison Control Centers, more than 2,000 cases have been identified in this regard until 2014 The common feature of abused antipsychotics is that they are dopamine antagonists that directly or indirectly increase release of dopamine to nucleus accumbens (14). The first case in the literature on abuse of quetiapine was explained in 2008. A 48-year-old male patient with alcohol and benzodiazepine drug addiction has been prescribed quetiapine at a dose of $100 \mathrm{mg}$ daily for 15 years for addiction treatment. The person

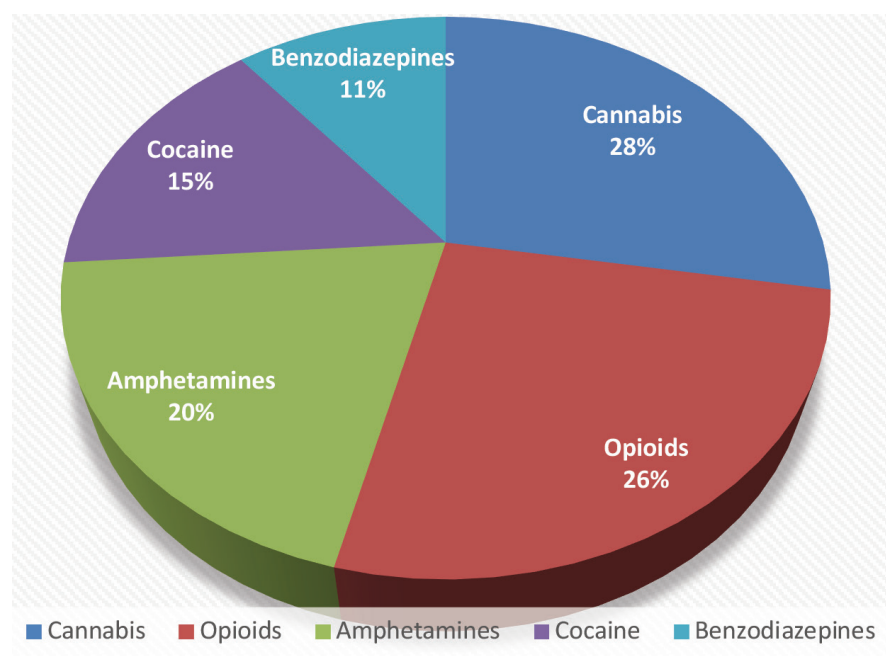

Figure 1. Frequencies of illegal substances used with quetiapine 
Table 1. MRM transitions and retention times of analytes molecular ion, fragments, fragmentation energy and retention time values

\begin{tabular}{|c|c|c|c|c|c|}
\hline No & Drug & R.T. (min.) & Precursor ion $(\mathrm{m} / \mathrm{z})$ & Product ion (m/z) & CE (Volt) \\
\hline \multirow{2}{*}{1} & \multirow{2}{*}{ Morphine } & \multirow{2}{*}{4.18} & \multirow{2}{*}{286.10} & 165.10 & -42 \\
\hline & & & & 153.20 & -45 \\
\hline 2 & Benzoylecgonine & 4.79 & 290.10 & 105.10 & -30 \\
\hline 3 & Codenine & 5.98 & 300.20 & 165.20 & -46 \\
\hline \multirow{2}{*}{4} & \multirow{2}{*}{ 6-Monoacetylmoprhine } & \multirow{2}{*}{6.38} & \multirow{2}{*}{328.20} & 211.00 & -28 \\
\hline & & & & 193.10 & -29 \\
\hline \multirow{2}{*}{5} & \multirow{2}{*}{ Methylinedioxyamphetamine } & \multirow{2}{*}{8.23} & \multirow{2}{*}{180.10} & 105.10 & -22 \\
\hline & & & & 135.10 & -2 \\
\hline 6 & Amphetamine & 7.86 & 136.10 & 91.10 & -20 \\
\hline & Methylinedinzymethamphetamine & 861 & 19410 & 105.10 & -23 \\
\hline 8 & I Iethylınedioxymetnampnetamine & 8.61 & 194.10 & 135.10 & -21 \\
\hline & & & & 299.20 & -20 \\
\hline 9 & THCCOOH & 9.10 & 345.30 & 193.10 & -27 \\
\hline & THC-OH & 940 & 33120 & 313.20 & -23 \\
\hline 10 & IHC-OH & 9.40 & 331.20 & 192.90 & -29 \\
\hline & & & & 123.00 & -30 \\
\hline 11 & $\triangle \mathrm{Y}-\mathrm{IHC}$ & 10.33 & 315.20 & 193.20 & -33 \\
\hline 15 & Fcoonine-methyl-ester & 322 & 20010 & 182.10 & -18 \\
\hline 15 & Ecgonine-metnyl-ester & $3 . \angle 2$ & 200.10 & 82.10 & -15 \\
\hline 16 & 7-aminoclonazenam & 616 & 28610 & 121.05 & -32 \\
\hline 16 & /-aminocionazepam & 6.16 & 286.10 & 222.10 & -26 \\
\hline & Clonazenam & & & 241.20 & -51 \\
\hline 17 & Clonazepam & 8.51 & 316.00 & 270.02 & -28 \\
\hline 18 & Fentany & 935 & 32730 & 188.15 & -23 \\
\hline 18 & Fentanyi & 9.35 & $33 / .30$ & 105.00 & -38 \\
\hline & & & & 154.20 & -28 \\
\hline 19 & Diazepam & 9.80 & 285.10 & 222.30 & -27 \\
\hline & & & & 91.05 & -32 \\
\hline 20 & Medazepam & 11.0 & $2 / 0.90$ & 207.10 & -29 \\
\hline & & & & 227.20 & -26 \\
\hline 21 & Diazepam-db (Internal standard) & 9.03 & 290.20 & 198.20 & -34 \\
\hline
\end{tabular}


reported that after a few weeks, the dose increased up to $1000 \mathrm{mg}$ of his own free will, sometimes in combination with clonazepam (15).

The European Drug Agency received 209571 adverse drug reaction reports of quetiapine in the period July 2005-July 2016, of which 18112 reports reported abuse, dependence and cessation of 884 patients and $8.6 \%$ of all adverse reactions. In this report, $1.02 \%$ of the cases were reported to be related to quetiapine abuse (16). The previous studies conducted were mostly based on the frequency of use of quetiapine among clinical cases. All cases that are the subject of our study are forensic cases. The results of the judicial investigation process evaluated together with the drug test and crime scene findings will determine whether these cases were drug dealers or users. The focus of this study is to determine the frequency of use of prescription quetiapine among dealers or users. Quetiapine abuse rate was determined as $1.16 \%(n=50)$ in this study which was carried out in Adana.

Quetiapine is known to be abused by prisoners, and many cases, including those published in our country, report that abused the drug in prison or while hospitalized by court order (17-19). However, several reports have also reported that widely abused this drug in psychiatric outpatient clinics such as Alcohol and Drug Addiction Research, Treatment and Education Center, Turkey (9). In addition, its abuse potential via snorting, smoking or intravenous by crushed and brought into street form is emphasized $(6,10)$. Abusers may obtain this uncontrolled drug in various ways, including getting it in black markets. They can obtain this drug by exaggerating their psychiatric symptoms and manipulating the physician they are treated with (9). In this way, the drug, which can be easily gotten with a prescription, is delivered to drug addicts, sellers

Table 2. Frequency of single and multiple use of quetiapine in studied cases

\begin{tabular}{|l|l|l|}
\hline \multicolumn{2}{|l|}{ Abused Drugs } & Number of cases $(\mathbf{n})$ \\
\hline \multicolumn{1}{|l|}{ QUETIAPINE } & 11 \\
\hline \multirow{5}{*}{ QUETIAPINE +} & THC & 10 \\
\cline { 2 - 3 } & COC+AMPH+THC & 8 \\
\cline { 2 - 3 } & AMPH & 3 \\
\cline { 2 - 3 } & OPI+COC & 3 \\
\cline { 2 - 3 } & AMPH+THC & 3 \\
\cline { 2 - 3 } & THC+OPI & 2 \\
\cline { 2 - 3 } & COC+AMPH+THC+BENZ & 2 \\
\cline { 2 - 3 } & AMPH+BENZ & 2 \\
\cline { 2 - 3 } & THC+OPI+BENZ & 1 \\
\cline { 2 - 3 } & OPI+BENZ & 1 \\
\cline { 2 - 3 } & COC+AMPH & 1 \\
\cline { 2 - 3 } & COC+BENZ & 1 \\
\hline
\end{tabular}

or users by establishing socail networks in jail or hospital and can be abused in street forms $(9,10)$. In a report on quetiapine abuse, a 33-year-old male who had substance addiction and admitted to the emergency room for rehabilitation and detoxification burglariously powdered quetiapine prescribed for his wife, mixed it with cocaine, and abused it intravenously $(20,21)$.

In 2014, Reddel et al. (22) In a recent prevalence study based on quetiapine abuse among users of illicit substances, $15 \%$ of quetiapine users have been identified. In addition, quetiapine-related deaths have generally occurred in cases of multiple drug use $(23,24)$. Some studies concurrently exploited sympathomimetics such as cocaine and other illegal substances, such as Methylinedioxymethamphetamine. According to the data obtained in our study, the abuse of quetiapine in cases who come to our forensic toxicology laboratory can be either alone or in combination with illegal drugs. When multiple and single substance use of quetiapine is evaluated together, illicit substances and abuse are as follows; marijuana $>$ opiate $>$ amphetamine $>$ cocaine $>$ benzodiazepine (Figure 2). According to World Drug Report of United Nations Office on Drugs and Crime in 2019, about 147 million people, 2.5\% of the world population, consume marijuana (25). These results show that prescription antipsychotics drugs such as quetiapine combined with drugs are abused in combination.

Epidemiological studies on the use of illicit drugs or prescription psychoactive drugs in Turkey are mostly based on surveys (26). Incorrect answers of the participants in the surveys conducted on the use of illicit or prescription drugs may restrict the study. In this respect, it is important to provide evidence-based medical approach and to determine the drug or illicit substance sought in biological samples. Therefore, the limitation of our study is that the validity of self-report to determine who was taking quetiapine therapeutically is problematic. However, it is not possible to reach therapeutic drug usage of these cases due to ethics and privacy.

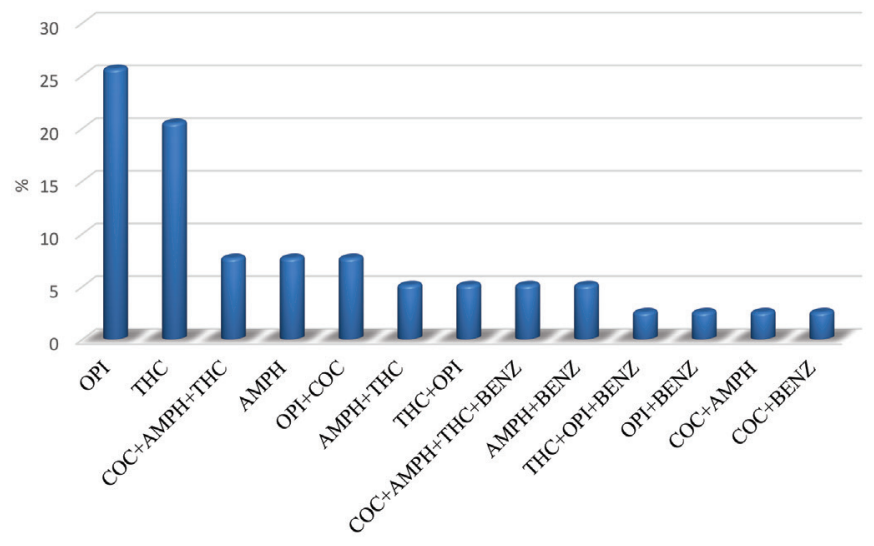

Figure 2. Frequencies of illegal substance and multiple substance groups used with quetiapine 


\section{Statistical Analysis}

Data collection, analysis and reporting systems have been developed abroad to assess and anticipate an expected increase in non-medical uses of especially prescription psychoactive drugs (27). In order to decrease the rate of drug abuse, it is important to control psychoactive drug prescriptions more closely, to be more careful clinicians in terms of dosage and usage follow-up of drugs that are likely to be abused, to detail the medical history of patients, to inform patients about drugs whose have potential for addiction and to increase the deterrent measures on people who take and sell psychoactive drugs by prescription. In 2013, with the circular issued by the Ministry of Health, Turkey Pharmaceuticals and Medical Devices Agency, many normal prescription drugs were followed due to drug abuse. Quetiapine is still not included in the list of controlled drugs in Turkey. The data obtained with this study of this drug will play an important role in taking the necessary measures by the relevant institutions. The limitations of our study include the lack of alcohol analysis in the cases due to not requesting alcohol analysis, not knowing the time from when there were suspicion of substance use to the time they came to the laboratory, not knowing how long the cases have been abusing the substance, and not reaching the clinical history. The prevalence of quetiapine usage was found to be low among people involved in drug-related crimes in our study (1.16\%). Therefore, although quetiapine investigation does not seem to be effective in terms of time and cost in every case, it can be concluded that quetiapine is included in qualitative general screening methods used in the routine analysis of forensic toxicology laboratories, and if necessary, it will be useful to perform quantitative analysis.

\section{CONCLUSIONS}

In this study, the most common use of cannabis and quetiapine was determined in cases with abuse of illicit substances. The monitoring of quetiapine is essential for preventing drug abuse especially in prone population such as illicit drug abusers and addicts. It is important to provide an evidence-based medical approach analysing biological samples to determine the drug or illicit substance usage.

\section{ETHICS}

Ethics Committee Approval: The study was approved by the Non-interventional Clinical Research Ethics Committee of the Faculty of Medicine in the Cukurova University (approval number: 93, approval date: 01.11.2019).

*This study was presented at the $57^{\text {th }}$ Annual Meeting of the International Association of Forensic Toxicologists in Birmingham, UK.

Informed Consent: Written informed consent was obtained from all the patients who took part in the study.
Peer-review: Internally peer-reviewed.

\section{Authorship Contributions}

Concept: I.E.G., N.D., Design: I.E.G., N.D., Data Collection or Processing: I.E.G., N.D., Analysis or Interpretation: I.E.G., N.D., Literature Search: I.E.G., Writing: I.E.G., N.D.

Conflict of Interest: No conflict of interest was declared by the authors.

Financial Disclosure: The authors declared that this study received no financial support.

\section{REFERENCES}

1. Piróg-Balcerzak A, Habrat B, Mierzejewski P. Niewłaściwe używanie nadużywanie kwetiapiny [Misuse and abuse of quetiapine]. Psychiatr Pol. 2015;49(1):81-93.

2. Klein-Schwartz W, Schwartz EK, Anderson BD. Evaluation of Quetiapine Abuse and Misuse Reported to Poison Centers. J Addict Med. 2014;8(3):195198.

3. Klein L, Bangh S, Cole J. Intentional recreational abuse of quetiapine compared to other second-generation antipsychotics. West J Emerg Med. 2017;18(2):243-250

4. Geda YE, Schneider LS, Gitlin LN, Miller DS, Smith GS, Bell J, et al. Neuropsychiatric symptoms in Alzheimer's disease: past progress and anticipation of the future. Alzheimer's \& dementia. 2013:9(5):602-608.

5. Sattar SP, Bhatia SC, Petty F. Potential benefits of quetiapine in the treatment of substance dependence disorders. J Psychiatry Neurosci. 2004;29(6):452457.

6. Pierre JM, Shnayder I, Wirshing DA, Wirshing WC. Intranasal quetiapine abuse. Am J Psychiatry. 2004;161(9):1718.

7. Dev V, Raniwalla J. Quetiapine. Drug Saf. 2000;23(4):295-307.

8. Cha HJ, Song MJ, Lee K-W, Kim EJ, Kim Y-H, Lee Y, et al. Dependence potential of tramadol: behavioral pharmacology in rodents. Biomol Ther (Seoul). 2014;22(6):558-562.

9. Vento AE, Kotzalidis GD, Cacciotti M, Papanti GD, Orsolini L, Rapinesi C, et al. Quetiapine abuse fourteen years later: where are we now? A Systematic Review. Subst Use Misuse. 2020;55(2):304-313.

10. Srivastava A, Patil V, Da Silva Pereira Y. A case series of quetiapine addiction/ dependence. Ger J Psychiatry. 2013;16(4):152-155.

11. Piróg-Balcerzak A, Habrat B, Mierzejewski P. Niewłaściwe używanie nadużywanie kwetiapiny [Misuse and abuse of quetiapine]. Psychiatr Pol. 2015;49(1):81-93.

12. Malekshahi T, Tioleco N, Ahmed N, Campbell ANC, Haller D. Misuse of atypical antipsychotics in conjunction with alcohol and other drugs of abuse. J Subst Abuse Treat. 2015;48(1):8-12.

13. Ramachandran S, Rosenthal M, Young J, Holmes E, Bentley JP. Subtle scales: An avenue for identification of prescription drug abuse. Res Soc Adm Pharm. 2019;15(8):936-942.

14. Finlayson A. Non-medical and illicit use of psychoactive drugs. vol. 34. v34 ed. Current Topic in Behavioral Neurosciences (Springer); 2017.

15. Paparrigopoulos T, Karaiskos D, Liappas J. Quetiapine. J Clin Psychiatry. 2008;69(1):162-163.

16. Chiappini S, Schifano F. Is There a Potential of Misuse for Quetiapine? J Clin Psychopharmacol. 2018;38(1):72-79.

17. Oyemade A. Seroquel misuse/abuse. Psychiatry (Edgmont). 2010;7(2):15

18. Tamburello AC, Lieberman JA, Baum RM, Reeves R. Successful removal of quetiapine from a correctional formulary. J Am Acad Psychiatry Law. 2012;40(4):502-508.

19. Kaya H, Dilbaz N, Okay T, Çeflmeci U. Is quetiapine addictive?-Turkish]. Klin Psikofarmakol Bul. 2009;19:32-37. 
20. Mutlu E, Așicioğlu F. Abuse of prescribed psychoactive drugs. Anadolu Psikiyatr Derg. 2020;21(2):195-202.

21. Waters BM, Joshi KG. Intravenous Quetiapine-cocaine use (“Q-Ball”). Am J Psychiatry. 2007;164(1):173-174.

22. Reddel SE, Bruno R, Burns L, Kirwan A, Lokuge K, Dietze P. Prevalence and associations of quetiapine fumarate misuse among an Australian national city sample of people who regularly inject drugs. Addiction. 2014;109:295302.

23. Lee J, Pilgrim J, Gerostamoulos D, Robinson J, Wong A. Increasing rates of quetiapine overdose, misuse, and mortality in Victoria, Australia. Drug Alcohol Depend. 2018;187:95-99.
24. Pilgrim JL, Drummer OH. The toxicology and comorbidities of fatal cases involving quetiapine. Forensic Sci Med Pathol. 2013;9(2):170-176.

25. UNODC, United Nations Office on Drugs and Crime. World drug report 2019 , Booklet 1-5. 2019. https://doi.org/10.18356/bdc264f4-en.

26. Ögel K. Madde Kullanım Bozuklukları Epidemiyolojisi. Türkiye Klin Dahili Tıp Bilim Derg Psikiyatr. 2005;1:61-64.

27. Hernandez SH, Nelson LS. Prescription drug abuse: Insight Into the epidemic. Clin Pharmacol Ther. 2010;88(3):307-317. 154. 